\title{
Potential of Indigenous Pesticidal Plants in the Control of Field and Post-Harvest Arthropod Pests in Bambara Groundnuts (Vigna subterranea (L.) Verdc.) in Africa: A Review
}

\author{
Nicodemus S. Tlankka ${ }^{1,2 *}$, Ernest R. Mbega1, Patrick A. Ndakidemi1 \\ ${ }^{1}$ Department of Sustainable Agriculture and Biodiversity Ecosystems Management, School of Life Science and Bio-Engineering, \\ The Nelson Mandela African Institution of Science and Technology (NM-AIST), Arusha, Tanzania \\ ${ }^{2}$ Centre for Research, Agricultural Advancement, Teaching Excellence and Sustainability in Food and Nutrition Security \\ (CREATES, FNS), The Nelson Mandela African Institution of Science and Technology, Arusha, Tanzania \\ Email: *tlankkan@nm-aist.ac.tz
}

How to cite this paper: Tlankka, N.S., Mbega, E.R. and Ndakidemi, P.A. (2020) Potential of Indigenous Pesticidal Plants in the Control of Field and Post-Harvest Arthropod Pests in Bambara Groundnuts (Vigna subterranea (L.) Verdc.) in Africa: A Review. American Journal of Plant Sciences, $11,745-772$.

https://doi.org/10.4236/ajps.2020.115054

Received: March 20, 2020

Accepted: May 25, 2020

Published: May 28, 2020

Copyright $\odot 2020$ by author(s) and Scientific Research Publishing Inc. This work is licensed under the Creative Commons Attribution International License (CC BY 4.0).

http://creativecommons.org/licenses/by/4.0/

\begin{abstract}
Bambara groundnuts (Vigna subterranea (L.) Verdc.) is an important leguminous crop native in Africa and is mainly cultivated for its highly nutritious grains. However, bambara groundnuts production is constrained by many insect pests including aphids (Aphids sp.), leaf hopers (Hilda patruelis), foliage beetles (Ootheca mutabilis), pod sucking bugs (Clavigralla tomentosicollis), red spider mites (Tetrunychus $s p$.), groundnut jassids in the field and bruchids (Callosobruchus maculatus, and Callosobruchus subinnotatus) in the storage. Smallholder farmers usually apply synthetic pesticides to control those insect pests. However, synthetic pesticides are potentially harmful to the environment, non-targeted animals and human's health. Pesticidal plants such as B. pilosa, L. camara, T. vogelii, V. amygdalina, L. javanica, T. diversifolia, and $C$. dichogamus which are available in most parts of Africa where the crop is cultivated, possess bioactive chemicals which have insecticidal properties and have been revealed to be potential in the control of field and storage insect pests. Therefore, they can be used as an alternative to synthetic pesticides. Bambara groundnuts being one of the neglected crops, the insects affecting the crop have not been well explored in terms of their abundance and damage they cause to the crop in the field and on storage. Thus, in this review, the common arthropod pests of the bambara groundnuts and the potential of the bioactive compounds from the common plants with pesticidal properties have been described. It is recommended that the potential of these
\end{abstract}


pesticidal plants to be investigated on bambara groundnut pests control on the field and on storage to optimize their use by smallholder farmers in insect control to reduce dependence on synthetic pesticides.

\section{Keywords}

Neglected Crop, Synthetic Pesticides, Bioactive Compounds, Insecticidal Properties

\section{Introduction}

Bambara groundnut (Vigna subterranea (L.) Verdc.) is an important leguminous crop indigenous in Africa [1] [2]. In many parts of Africa, it is ranked the third after peanut (Arachis hypogaea) and cowpea (Vigna unguiculata) in terms of consumption and socio-economic importance [3] [4] [5]. The grains are highly nutritious containing approximately $15 \%-25 \%$ protein, $49 \%-63.5 \%$ carbohydrate, $4.5 \%-7.4 \%$ fat, $5.2 \%-6.4 \%$ fiber, and $2 \%$ mineral thus, it is regarded as complete food [6] [7]. Moreover, bambara groundnut is highly tolerant to drought and temperature and it can grow and yield in poor soils [5] [8] [9] [10] [11]. Being a leguminous crop, bambara groundnuts have the ability to fix soil nitrogen of about $20-100 \mathrm{~kg} \cdot \mathrm{ha}^{-1}$ to the soil useful in crop rotations and intercropping with non-nitrogen fixing crops [11]. Bambara groundnut is mainly produced for consumption and it serves as a food security crop, eaten as freshly cooked pods or as dry grains incorporated into main dishes such as cooked plantains and cereals [12]. Moreover, bambara groundnuts serve as a source of income among smallholder farmers especially when the yields of other crops are low due to the prevailing drought and extreme temperatures and crop residues are used to feed livestock [11] [13] [14]. Although bambara groundnut has remained underutilized and under-researched [11]. However, currently, the crop has attracted research attention and cultivation by farmers mainly due to its climate resilience, unlike other legumes that are at risk due to climate change effects [14] [15].

The world production of bambara groundnut in 2016 was estimated by FAO to be 164,589 tonnes whereby the main production is from African countries such as Mali, Cameroon, Niger, Burkina Faso and Democratic Republic of Congo (DRC) [16]. In Tanzania, the bambara groundnuts are cultivated in Kagera, Mara, Mwanza, Shinyanga, Tabora, Singida, Dodoma, Rukwa, Iringa, Lindi, Ruvuma and Mtwara regions [12]. However, in Tanzania, the yield of bambara groundnut is $500-800 \mathrm{~kg} \cdot \mathrm{ha}^{-1}$ which is lower than the potential yield of 1500 $2000 \mathrm{~kg} \cdot \mathrm{ha}^{-1}$ under proper crop management [17]. Despite the nutritional and economic potentials for the smallholder farmers, bambara groundnut production is constrained by insect pests including aphids (Aphids sp.), leafhoppers (Hilda patruelis) and bruchids (Callosobruchus maculatus, and C. subinnotatus) 
[15] and, brown leaf beetles (Ootheca mutabilis), groundnut jassid (Empoasca facialis) [18], red spider mites (Tetrunychus sp.) [19], pod sucking bugs (Clavigralla tomentosicollis Stäl) [20].

In bambara groundnut farming, the use of pesticides is generally on a small scale mainly because bambara groundnut is a neglected crop or orphan crop (Hillocks et al., 2012) leading to less application of agricultural inputs such as pesticides to maximize the potential productivity of the crop [3]. However, in an attempt to control pests, the smallholder farmers apply synthetic pesticides as the major insect control strategy and have always provided effective control against insect pests [21] [22]. However, synthetic insecticide has detrimental effects on the health of the pesticide applicators, consumers, and is not environmental benign [23] [24] [25] [26]. These undesirable impacts of synthetic pesticides have raised global concern paving a way to research plants with toxicity to the insect which may be used instead of synthetic insecticides. The use of pesticidal plants is a promising alternative to synthetic pesticides. Several studies revealed that, the pesticidal plant extracts are effective to control insect pests on crops [27]-[33]. Moreover, pesticidal plants are easily available, degradable in the environment and less toxic to human and non-targeted organisms [28], therefore they can be used by smallholder farmers to control insect pests in their crops including the bambara groundnuts with less detrimental effects to the environment, human health and to the natural enemies.

\section{Review Method}

We conducted a review of the literature related to the bambara groundnut pests as well as the pesticidal plants commonly used in Africa for different purposes but we mainly focused on pesticidal uses. A comprehensive review was conducted on the key pests constraining the bambara groundnuts production with the main focus on their distribution, damage symptoms on plants, and management strategies. Due to limited information on bambara groundnut pests, we tried to search for information on particular pests on different crops and specifically legumes. Concerning pesticidal plants, we searched documents related to their distribution, traditional uses, photochemistry, and research findings on their pesticidal potential. The primary source of information used in this review includes Google books, conference proceedings, research papers, and review articles and reports retrieved from the online databases such as Google Scholar and Google using keywords like "bambara groundnuts", "Insect pests + bambara groundnuts", Pesticidal plants," "Impacts of synthetic pesticides". More specific keywords such "pesticidal potential of Bidens pilosa, Lantana camara, Tephrosia vogelii, Vernonia amygdalina, Lippia javanica, Tithonia diversifolia and Croton dichogamus" were used to get the required detailed information. We managed to review 125 documents ( 109 articles, 5 online books, 5 conference proceedings, 6 institutional reports) related to bambara groundnuts, bambara groundnuts pests, legume pests, and pesticidal plants. 


\section{Review Findings}

\subsection{Key Arthropod Pests Affecting Bambara Groundnuts}

Bambara groundnuts are relatively tolerant to insect pests and diseases [11]. However, some literatures have reported that the crop is affected by the wide range of insect pests in the field, storage, and fungal diseases such as Cercospora leaf spot (Cercospora spp.), powdery mildew (Erysiphe polygoni) and fusarium wilt (Fusarium oxypolygoni) [18]. In this review, the insect pests affecting the bambara groundnuts including aphids (Aphis sp.), leafhopper (Hilda patruelis), groundnut jassid (Empoasca facialis), and brown leaf beetles (Ootheca mutabilis), red spider mites (Tetrunychus sp.) [19], pod sucking bugs (Clavigralla tomentosicollis Stäl) [20] in the field and bruchids (Callosobruchus macularus and C. subinnotatus) on the storage [15] [18].

\subsection{Aphids (Aphis spp.)}

Aphids (Aphis spp.) (Hemiptera: Aphididae) are small sap-sucking insects widely distributed in Africa. There are about 5000 species of aphids but only 450 species have been recorded on crop plants [34]. Out of 450 species recorded on crop plants, it is only 100 species that are of agricultural importance [34]. Bambara groundnut is one of the crop infested by aphids [15] [18]. For instance, in Zimbabwe, aphids represent about $65 \%$ of the insect pest problem in bambara groundnuts [12]. Aphids damage plants in all stages of growth from the seedlings stage to flowering (Figure 1), pod formation, and seed filling [35]. They tend to form colonies in leaves, stems, and pods where they damage crops by sucking sap from the plant during feeding and also transmit disease-causing viruses such as rosette virus or through injecting deleterious toxins into the plants [35]. The heavily infested plants can wilt and turn yellow or die due to the removal of sap from the plant [12]. The main aphids control strategies in crops include cultural practices such as early planting, use of resistant varieties, physical control and application of chemical insecticides such as phosphamidon, dimethoate, thiometon pirimicarb. However, due to the undesirable effects of synthetic pesticides, its use is discouraged [36]. The biological control such as the use of natural enemies such as parasitic wasps, hoverfly larvae, lacewings, and ladybird beetles which predate on aphids help in suppressing the population of aphids [34]. Pesticidal plants, on the other hand, have provided promising results in aphid's control. For example, Mkindi et al. (2017) reported that pesticidal plants such as Bidens pilosa, Lantana camara, Tephrosia vogelii, Vernonia amygdalina, Lippia javanica, and Tithonia diversifolia were effective against aphids (Aphis fabae) on common beans. Furthermore, these pesticidal plants cause very little effect on beneficial arthropods as compared with synthetic pesticides [30]. Therefore, future research is needed to quantify the abundance of aphids on bambara groundnuts and the damage caused by them in different cropping systems and to test the effectiveness of the available pesticidal plants to be used as an alternative of synthetic pesticides in Tanzania. 


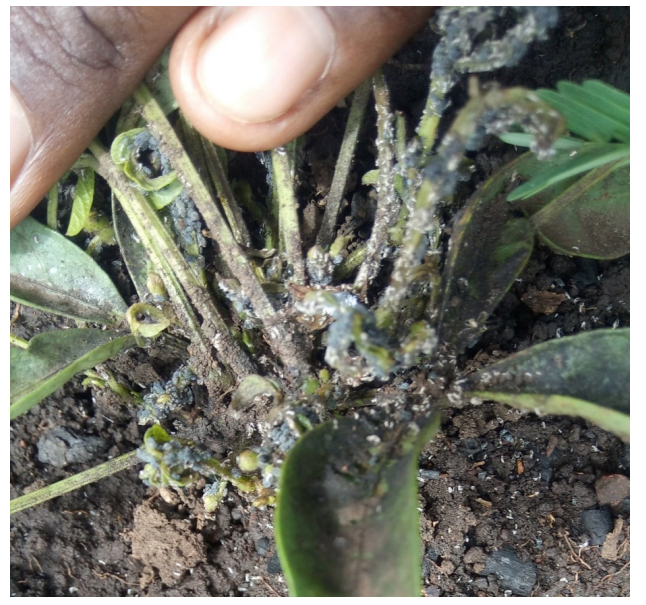

Figure 1. Aphids on bambara groundnut plant (Source: Field photo).

\subsection{Groundnut Leafhopper (Hilda patruelis Stal)}

The groundnut hopper, Hilda patruelis Stal (Homoptera: Tettigometridae) are polyphagous sucking bug widely distributed in Africa [37] [38]. It is one of the important insect pests of bambara groundnuts severely affecting their productivity [18] [39]. They usually attack plants below the ground level or at the ground level [37]. During their feeding process, Hilda bugs tend to inject toxic saliva on the plants resulting in withering and ultimately dying of the plants. They are usually noticed by the presence of the colonies of black ants which tend to protect them [37]. The leafhoppers and ants coexist in symbiotic relationship where the leafhoppers produce honey-dew which provides food for the ants while ants protect the leafhoppers against predators [37]. The adult leafhoppers damage the crop by sucking sap from the stem, pegs, and pods resulting in wilting of the plants [40]. The affected plants turn yellow, wilt, and die due to sap-sucking by the hoppers [37] [41]. Although, it is regarded as a minor pest, however, sporadic infestation during the dry season may lead to significant loss of yield if left uncontrolled [37]. However, in Tanzania, there is a lack of information on this insect due to little research attention on bambara groundnuts as it is considered as an under-researched orphan crop [3]. Therefore, further research should focus on determining the abundance and assess the impact of $H$. patruelis on bambara groundnuts grown in different cropping systems and patterns.

\subsection{Foliage Beetles (Ootheca mutabilis, Ootheca bennigseni)}

Foliage beetles ( $O$. mutabilis, and $O$. bennigseni) (Coleoptera: Chrysomelidae) are foliage eating insects that are widely distributed in southern and eastern Africa including Tanzania [42]. Leaf beetles are important insects affecting, common beans, cowpea, and bambara groundnuts [18] [42] [43]. They feed on root tissue and seedlings, make holes in the leaves of host plants (Figure 2), and often feed on flowers, resulting in crop losses usually when the crop is at the seedling stage. Ootheca spp. are also vectors of plant viruses [43]. The infestation by Ootheca spp. is most severe on young plants; however, sometimes it may 


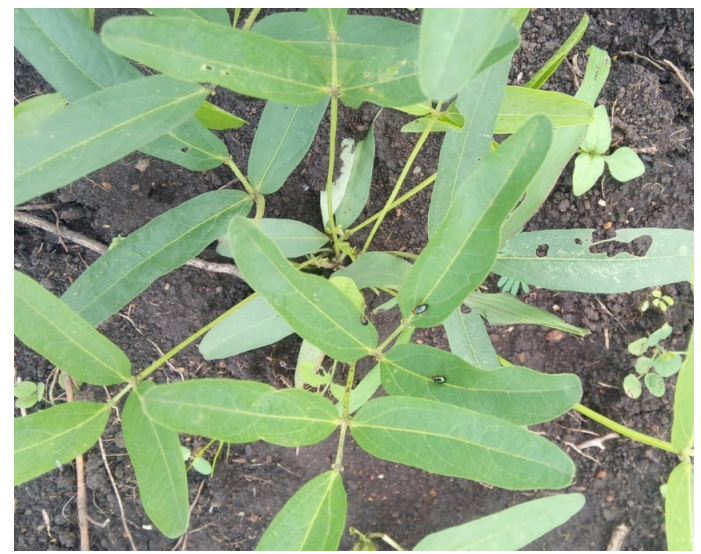

Figure 2. Foliage beetles on bambara groundnut plant (Source: Field photo).

persist up to post-flowering. The adult beetles feed on leaves reducing the photosynthetic activity of the plant and may even cause the death of the plants especially if there is a severe attack on the growing points [42]. In common beans, the yield losses of $18 \%-31 \%$ attributed by foliage beetles in Tanzania have been reported (Abate \& Ampofo, 1996). Unfortunately, in Tanzania, there is published information on the magnitude of the impact of this insect pest on bambara groundnuts.

\subsection{Groundnut Jassids (Empoasca fascilis)}

Groundnut jassids Empoasca fascilis (Homoptera: Cicadellidae) are small green insects widely distributed in Africa [38] [44]. E. fascilis is one of the important insect pests of bambara groundnuts in Africa [18]. The adults and nymphs pierce and suck on the lower surfaces of the leaf leading to the yellowing of the leaves [38]. Damage by many jassids on one leaf leads to yellow spots followed by crinkling, curling, bronzing, and drying of the plants [38]. A yield loss of $3.5 \%-39.5 \%$ has been reported in soybeans depending on the susceptibility of the variety [45]. The jassids population growth is generally enhanced by dry and humid conditions. The management strategies include cultural practices such as intercropping with non-legume crops and the use of systemic insecticides. However, the use of synthetic insecticides kills the natural enemies which prey on the adult and nymphs regulating the population of jassids. Thus, future research is needed to look for strategies that have less impact on natural enemies such as the use of extracts from the pesticidal plants.

\subsection{Pod Sucking Bugs (Clavigralla tomentosicollis Stäl)}

Pod sucking bugs, Clavigralla tomentosicollis Stäl. (Hemiptera: Coreidae) are pods sucking bugs that are predominantly spread in tropics and sub-tropics of Africa [44]. It is one of the important pests of bambara groundnuts [20]. The nymphs and adults pierce and bugs suck the sap from the young pods leading to the deformation of seeds, necrosis, premature drying of the pods, and poor seed formation which ultimately results to low grain yield [42] [44]. They also feed on 
stems, leaves, and floral buds. [44]. The insect can cause grain yield loss ranging from $20 \%-100 \%$ when left uncontrolled on susceptible crops especially during prolonged dry weather [46]. Cultural practices such as intercropping legumes including bambara groundnuts with cereals can reduce the bugs infestation [44]. The biological control such as the use of Gryon fulviventris parasitoid can control C. tomentosicollis in Africa [44]. Synthetic insecticides can also be used to control bugs, however, they may kill even beneficial insects such as parasitoids G. fulviventris [44]. Pesticidal plants such Bidens pilosa, Lantana camara, Tephrosia vogelii, Vernonia amygdalina, Lippia javanica and Tithonia diversifolia on the other hand have provided effective control of insect pests on common beans insect pests including C. tomentosicollis [29]. Thus, future research is needed to be conducted to test the effectiveness of these pesticidal plants to control pod bugs on bambara groundnuts.

\subsection{Red Spider Mites (Tetrunychus sp.)}

Red spider mites, Tetrunychus sp. (Acari: Tetranychidae) are highly polyphagous mites originated in Eurasia but they are now widely distributed worldwide [47]. Red spider mites affect a wide range of crops including tomato, cucumber, pepper, rose, strawberry, currant, peach, grapes [47], common beans [42] and bambara groundnuts [19]. The damage of crops by red spider mites depends on the ability of the plant to resist damage. On susceptible crop, spider mites feed on leaves undersides by extracting the plant's sap using their long needle-like mouthparts resulting in the formation of brownish spots and often form webs on plants leaves [42]. In severe infestation, the leaves dry and dry off resulting (Figure 3) in the wilting of the entire plant [44]. The loss of yield of up to $100 \%$ has been reported on infested tea [48] and tomato [49]. The infestation of spider mites population is influenced by environmental factors such as low relative humidity, high temperature, drought, and long sunshine hours [50]. [49] reported that spider mites are difficult to control. Farmers often use ineffective broad-spectrum synthetic pesticides to control spider mites resulting in pest resistance [49]. The use of broad-spectrum synthetic pesticides tends to kill the

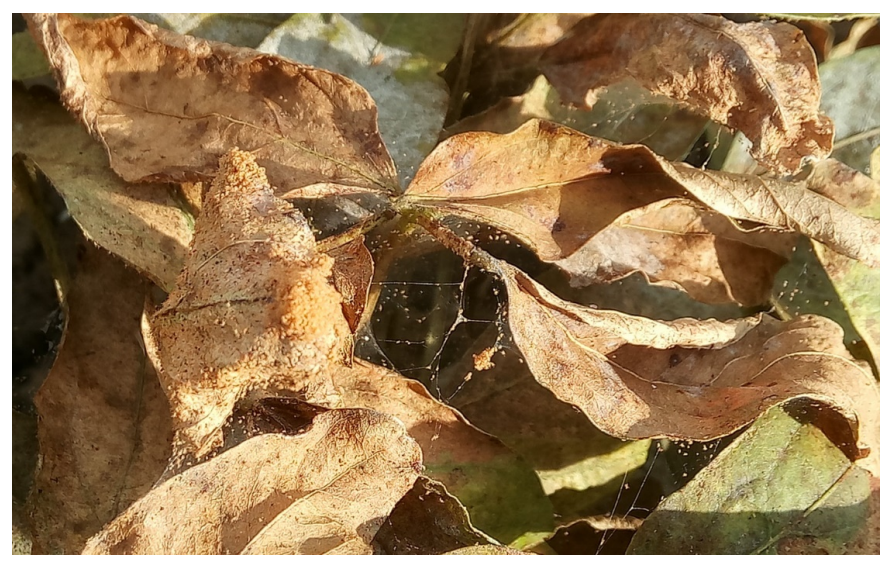

Figure 3. Spider mites on bambara groundnut plant (Source: Field photo). 
natural enemies which would regulate the population of the spider mites [44]. Moreover, predatory mites such as Phytoseiulus persimilis, Amblyseius womersleyi and A. fallacies (Acari: Phytoseiidae) are effective to control red spider mites under controlled structures and high relative humidity [44]. However, the synthetic insecticides applied also kills beneficial mites. Pesticidal plants, on the other hand, have been reported to reduce spider mites without or with little harm to the natural enemies. For instance, studies by [51] have revealed pesticidal efficacy of the Lippia javanica and Solanum delagoense on red spider mites on rapes and tomatoes [51]. It was found that both $L$. javanica and $S$. delagoense reduced mites by $66.5 \%$ and $55 \%$ respectively. Despite of the reported effectiveness of, $L$. javanica and $S$. delagoense on spider mites on rapes and tomato, however, there is no published information on their effectiveness on bambara groundnuts spider mites. Thus future research is recommended to investigate the efficacy of indigenous pesticidal plants on bambara groundnut spider mites.

\subsection{Bruchids Callosobruchus maculatus (F.) and Callosobruchus subinnotatus (Pic)}

Bruchids, C. maculatus and C. subinnotatus (Coleoptera: Bruchidae) are serious pests of grain bambara groundnuts in Africa [20] [52]. C. maculatus are widely distributed and believed to originate in Africa while $C$. subinnotatus is mainly localized in West Africa [53]. These two bruchids species often infest grain bambara groundnuts simultaneously. When these two species simultaneously infest bambara grains, they tend to exhibit interspecific competition where $C$. maculatus dominates over C. subinnotatus [54] [55]. It is reported that C. maculatus is the most destructive species enhanced by its shorter life cycle and high reproductive potential and it often infests a wide range of legume grains while $C$. subinnotatus infest only bambara grains [52] [55]. During co-infestation, $C$. maculatus can cause the extinction of $C$. subinnotatus in multiple generations [55].

Bruchids affect bambara groundnuts from the field to the storage. Being field to storage pests, their infestation commences in the field during the pod's stage whereby the females lay their eggs on developing seeds or pods or during the harvesting when the pods are left in the field to dry (Ajayi \& Lale, 2000; Nyamador et al., 2016). Bruchids on stored bambara groundnuts grains, reduce the quality and quantity of grains, and reduce the seeds germination potential and market value of the grains. The grain loss of up $99 \%$ has been reported when grains of susceptible variety is left unprotected with insecticide [56]. The infestation on the storage is influenced by the level of initial infestation thus the proper strategy of protection of bambara groundnuts grains from bruchids infestation starts by preventing the pre-harvest infestation on the field and post-harvest infestation during storage [55]. Various strategies are applied to control bruchids such as cultural control measures, breeding for resistance, synthetic insecticides, and pesticidal plants [52]. The use of pesticidal plants has been reported to be effective control of storage insects it does not cause an undesirable impact on the 
health of consumers, applicators, and nor-target organisms [27] [33]. Thus, more research is needed to determine the efficacy of pesticidal plants in the control of bruchids in bambara groundnuts.

\section{Prospects of Pesticidal Plants in Bambara Groundnut Insect Pest Control in the Field and Storage}

Pesticidal plants contain a mixture of bioactive compounds that act as feeding deterrents, repellents on insects or they tend to interfere with insect development [57]. They have been used by farmers for decades for pest control in crops or livestock (Table 1) before and after the introduction of synthetic pesticides (Anjarwalla et al., 2016). Unlike synthetic pesticides that have a detrimental effect on the environment, non-target organisms, and humans, pesticidal plants serve as better alternatives to synthetic insecticides since they are friendly to the environment and the health of farmers and consumers [28] [58]. This review has explored the chemical compounds, potential in controlling insect pests in the field, and storage of seven selected candidate pesticidal plants including Bidens pilosa, Lantana camara, Tephrosia vogelii, Vernonia amygdalina, Lippia javanica and Tithonia diversifolia and Croton dichogamus.

Table 1. Common pesticidal plants found in Africa.

\begin{tabular}{|c|c|c|}
\hline Pesticidal plan & Crop/insect controlled & Reference \\
\hline Pyrethrum, & Groundnut anthropods pests: & \\
\hline $\begin{array}{l}\text { Chrysanthemum } \\
\text { cinerariifolium }\end{array}$ & $\begin{array}{l}\text { Helotrichia serrate, Peridontopyge spp., } \\
\text { Macrotermes bellicosus }\end{array}$ & {$[59]$} \\
\hline Neem, Azadirachta indica & The Bean Weevil: Acanthoscelides obtectus & {$[60]$} \\
\hline Black jack, Bidens pilosa & $\begin{array}{l}\text { Common beans insect pests: Ootheca mutabilis } \\
\text { and } O \text {. bennigseni, Epicauta albovittata and } \\
\text { E. limbatipennis, Clavigralla tomentosicollis, } \\
\text { and } C \text {. hystricodes }\end{array}$ & {$[29]$} \\
\hline $\begin{array}{l}\text { Mexican marigold, } \\
\text { Tagetes minuta }\end{array}$ & Cabbage: Brevicoryne brassicae & {$[61]$} \\
\hline Tickberry Lantana camara & Maize weevil: Sitophilus zeamais & {$[62]$} \\
\hline Tobacco, Nicotiana tabacum & The Bean Weevil: Acanthoscelides obtectus & {$[60]$} \\
\hline $\begin{array}{l}\text { Fish poison, } \\
\text { Tephrosia vogelii }\end{array}$ & $\begin{array}{l}\text { Common beans insect pests: Ootheca mutabilis } \\
\text { and } O \text {. bennigseni, Epicauta albovittata and } \\
\text { E. limbatipennis, Clavigralla tomentosicollis, } \\
\text { and C. hystricodes }\end{array}$ & {$[29]$} \\
\hline Bitter leaf, Vernonia amygdalina & Cowpea beetle: Callosobruchus maculatus & {$[63]$} \\
\hline Lippia javanica & $\begin{array}{l}\text { Common beans insect pests: Ootheca mutabilis } \\
\text { and } O \text {. bennigseni, Epicauta albovittata and } \\
\text { E. limbatipennis, Clavigralla tomentosicollis } \\
\text { and } C \text {. hystricodes }\end{array}$ & [29] \\
\hline $\begin{array}{l}\text { Mexican sunflower, } \\
\text { Tithonia diversifolia }\end{array}$ & Cowpea beetle: Callosobruchus maculatus & {$[63]$} \\
\hline Eucalpytus sp. & Cereals: Sitophilus oryzae & {$[64]$} \\
\hline Garlic, Allium sativum & Maize: Sitophilus zeamais & {$[65]$} \\
\hline Derris elliptica & Cabbage: Brevicoryne brassicae & {$[66]$} \\
\hline Papaya, Carica papaya & Mustard Lipaphis erysimi & {$[67]$} \\
\hline Croton dichogamus & Storage insect pests & {$[67]$} \\
\hline
\end{tabular}




\subsection{The Chemical and Insecticidal Potential of Croton dichogamus}

Croton dichogamus Pax is a naturally growing shrub belonging to the family Euphorbiaceae widely distributed in tropics and subtropics such as Kenya, Uganda, Ethiopia, Mozambique, Madagascar and Tanzania ([69] [70] Figure 4). In Africa, America and Asia croton species are used as traditional medicines in the treatment of various ailments such as fever, diabetes, dysentery, wounds, ulcers malaria, intestinal worms, inflammation, hypercholesterolemia, digestive problems, constipation, cancer weight loss and pains [71]. In Kenya and Tanzania, $C$. dichogamus is used as a dietary additive to milk and soup. The smoke from the Croton is inhaled during the treatment of respiratory infections. Moreover, it has been reported that the plant is also used to treat chest pains, malaria, arthritis, gonorrhea, and stomachache in Kenya [70].

The photochemistry of the plant is generally diverse possessing the compounds such as crotodichogamoin A and B (Figure 5), crotofolanes, halimes, crothalimene A and B, crotohaumanoxide, aleuritolic, depressin, casbane and sesquiterpenoid are isolated from the roots of $C$. dichogamus [69] [70]. Most of the croton species are rich in terpenoids [71], a compound with insecticidal properties [72] [73]. Silva et al. (2018) studied the effectiveness of the ethanolic extracts from the leaves and stems of Croton rhamnifolius, C. jacobinensis, C. sellowii, and C. micans against the diamondback moth (Plutella xylostella $\mathrm{L}$ ) on kales. It was found that the $C$. rhamnifolius leaf had more lethal effect $\left(\mathrm{LC}=14.95 \mathrm{~mL}^{-1}\right)$ than the stem $\left(\mathrm{LC}=42.40 \mathrm{~mL}^{-1}\right)$ and $C$. sellowii stem was found to have the lowest lethal effect $\left(\mathrm{LC}=1252 \mu \mathrm{g} \cdot \mathrm{mL}^{-1}\right)$. In Tanzania, the plant is used by agro-pastoral societies in Mbulu District as a pesticide for controlling storage insect pests, medication of teeth infections and urinary tract infection [68]. Despite $C$. dichogamus being used traditionally by agro-pastoral societies in Mbulu, proper application rates have not been established for optimized application. Therefore, future research is needed to establish its dosages for proper insect pest control.

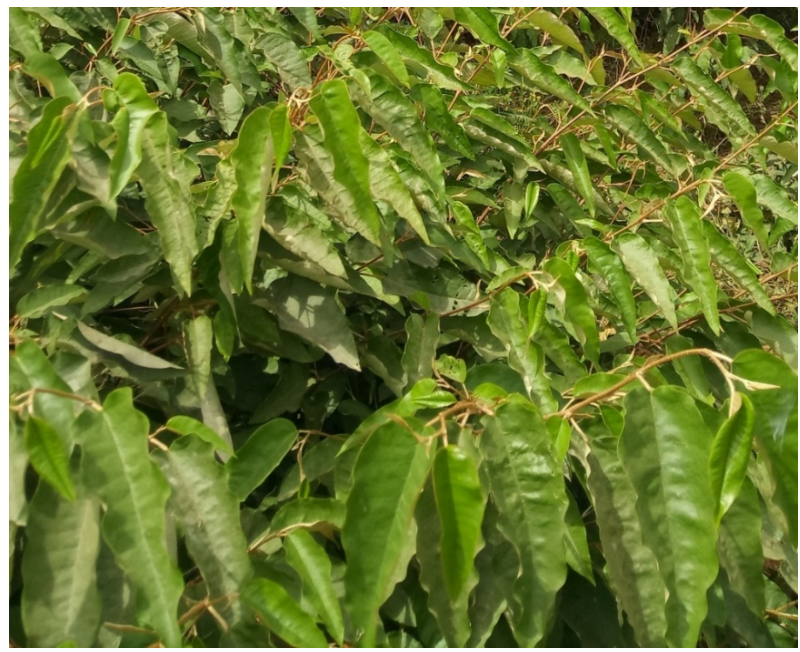

Figure 4. The picture of Croton dichogamus, a pesticidal plant (Source: Field photo). 


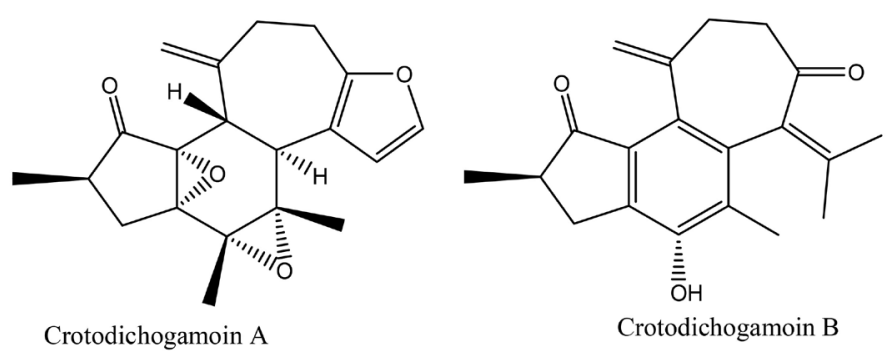

Figure 5. Chemical structure of crotodichogamoin A and B from C. dichogamus roots (Aldhaher et al., 2017).

\subsection{The Chemical and Insecticidal Potential of Tithonia diversifolia}

Tithonia diversifolia commonly known as Mexican sunflower is a prolific flowering shrub belonging to the family Asteraceae originated from central and north America [74]. Currently, Tithonia (Figure 6) is widely distributed along with the farms, roads, rivers, and hills of humid and sub-humid tropics of Africa, Central America and South America [75] [76]. Extracts from the T. diversifolia plant is traditionally used as medicine for the cure of many ailments including wounds, skin diseases, stomachache, malaria, diabetes, sore throat, fever and liver pains [76] [77] and insect pests control [29]. The medicinal and insecticidal properties of the plant are attributed by the presence of phytochemical constituents including sesquiterpene lactones tagitinin A, taginin B, tagitinin C, tagitinin $\mathrm{D}$ and tagitinin $\mathrm{H}$ (Figure 7) [63] [74].

Several authors including Green et al. (2017) reported the insecticidal potential of $T$. diversifolia against cowpea bruchids Callosobruchus maculatus. It was revealed that the toxicity of crude extracts of $T$. diversifolia against bruchids was concentration-dependent. However, it was found that the crude extracts showed no significant effect on the oviposition despite the concentration. Other studies by [28] [29] found that the leaf extracts of the $T$. diversifolia was effective against the insect pest of common beans such as aphids (Aphis fabae), bean foliage beetle (Ootheca mutabilis and $O$. bennigseni) and flower beetle (Epicauta albovittata and E. limbatipennis). The application of T. diversifolia as pesticide reduces the cost incurred on expensive synthetic pesticides resulting in the high marginal rate of returns from farming. For example, the use of $T$. diversifolia is reported to provide the marginal rate of return of $5.32 \mathrm{USD} /$ ha higher than 4.06 USD/ha obtained when synthetic pesticide is used [28]. The leaves of the T. diversifolia contain nutrients about $3.5 \% \mathrm{~N}, 0.37 \% \mathrm{P}$, and $4.1 \% \mathrm{~K}$ on dry matter basis so when used as green manure replenishes soil nutrients enhancing the growth and yield of the crops [75]. Moreover, foliar spraying of the extract from these plant as a pesticide it also provide additional nutrients to the crop in the form of foliar fertilizer [78], thus, resulting to high yield of the crop. Furthermore, plants are also used as animal fodder [79].

Therefore, the presence of the bioactive compounds in these plants, and proven pesticidal potential against arthropod pests of legumes [28] [29] [63] 


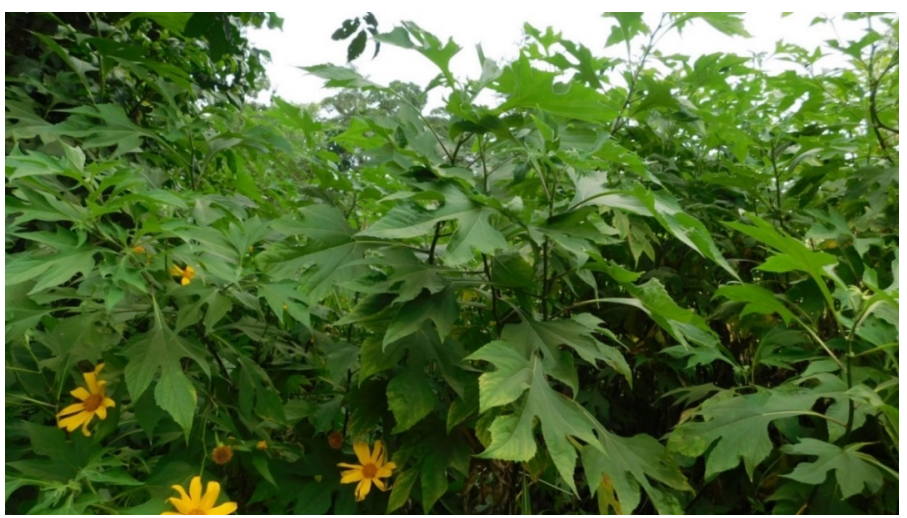

Figure 6. The picture of Tithonia diversifolia, a pesticidal plant (Source: Field photo).<smiles>[R]C1C[C@@]2(O)C[C@H]3OC(=O)C(=C)[C@@H]3[C@H](OC(=O)C(C)C)C[C@]1(C)O2</smiles>

$1 \mathrm{R}=\mathrm{OH}$

1a $\mathrm{R}=\mathrm{OAc}$

Tagitinins A<smiles>C=C1C(=O)O/C=C\C(=O)/C(C)=C\[C@@](C)(O)C[C@@H]1[C@@H](OC(=O)C(C)C)C(=O)O</smiles>

Tagitinins C

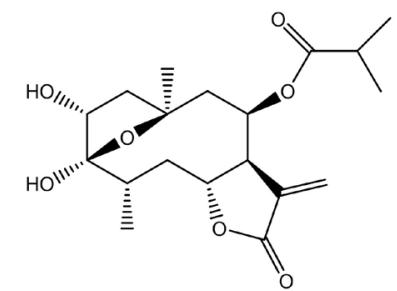

2 alpha -hydroxytirotundin, tagitinins $\mathrm{A}$ isomer<smiles>C=C1C(=O)O[C@H]2/C=C(\C)[C@@]3(O)O[C@@](C)(C[C@@H]2OC(=O)C(C)C)[C@@H]13</smiles>

Tagitinins B

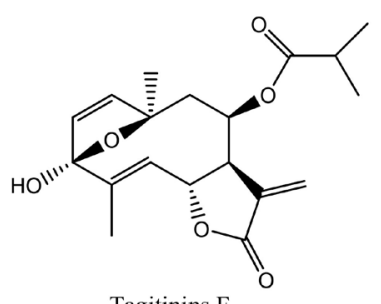

Tagitinins F

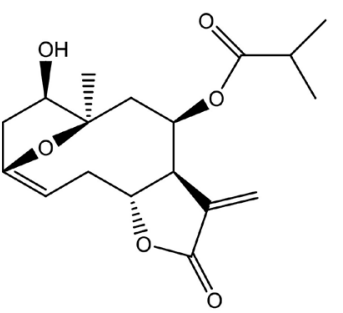

Dehydrated tagitinins $A$

Figure 7. Chemical structure of sesquiterpene lactones tagitinin A, tagitinin $B$, taginin $C$ taginin $\mathrm{F}$ and taginin 2 alpha-hdroxytirotundin, taginins $\mathrm{A}$ isomer and dehydrated taginins A (Green et al., 2017; Miranda et al., 2015; Zhao et al., 2012).

gives the insight to investigate its effectiveness in the control of pre-harvest and post-harvest insect pest of bambara groundnuts.

\subsection{The Chemical and Insecticidal Potential of Lantana camara}

L. camara (Figure 8) is an ornamental plant in the family Verbenaceae originated from America. It is widely spread in tropical and subtropical regions 


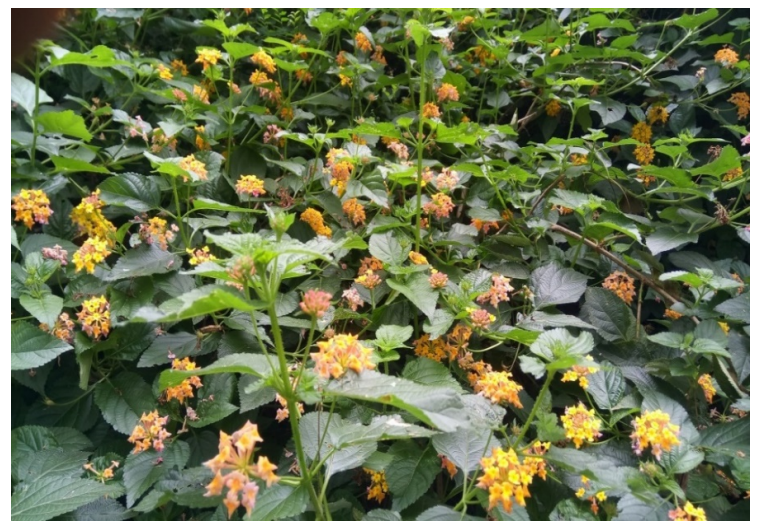

Figure 8. The picture of Lantana camara, a pesticidal plant (Source: Field photo).

including East Africa [80]. In many parts of the world, it is considered an invasive weed [80] [81] [82]. It is used in the preparation of the folk medicine for the cure of ailments diseases such as ulcers, rheumatism, tetanus, malaria, cancer, ulcers, cancer, eczema, high blood pressure, sores and measles among others [83] [84] [85] [86]. L. camara is regarded as toxic to livestock such as cattle, sheep, horses, dogs, and goats [30] [87].

The toxicity to animals is caused by the presence of pentacyclic triterpenoids (Figure 9) which damage liver and generalized weakness, diarrhea, vomiting and notorious to cause photosensitivity [88]. The toxicity in humans is undetermined but several studies have suggested that ingesting green unripe fruits are toxic to humans [88] [89]. However, other studies have reported that the ingestion of ripe fruits poses no risk to humans [88] [89]. Several studies have revealed the insecticidal property of $L$. camara against several insect pests of stored grains. For example, the study conducted in Kenya by Ogendo et al. (2003) reported the insecticidal potential of leaf powder from $L$. camara against maize weevil (Sitophilus zeamais). Their study revealed that after 21 days $L$. camara at the rate of $7.5 \%-10 \% \mathrm{w} / \mathrm{v}$ resulted in $82.7 \%$ insect mortality. Moreover, another study by Rajashekar et al. (2014) reported the potential of $L$. camara in control of Sitophilus oryzae (L.) Callosobruchus chinensis (Fab.) and Tribolium castaneum (Herbst.). Despite the findings available, there is a need to conduct more studies to understand the potential of $L$. camara against different insect pests on different crops both in the field and on storage.

\subsection{The Chemical and Insecticidal Potential of Bidens pilosa}

Bidens pilosa L. is an annual herb originated from South America and widely distributed around the tropical and subtropical regions [90] [91]. The plant is regarded as a noxious weed in the agricultural fields [92]. In sub-Saharan countries, the young tender leaves (Figure 10) are consumed as a vegetable in times of food scarcity [92]. The medicinal role of the plant in many parts of the world such as Africa, Asia, and tropical America includes anti-inflammation, anti-bacterial infection, antioxidant, liver protection, regulating blood pressure and blood sugar has been extensively described by many authors [92] [93] [94] [95]. 

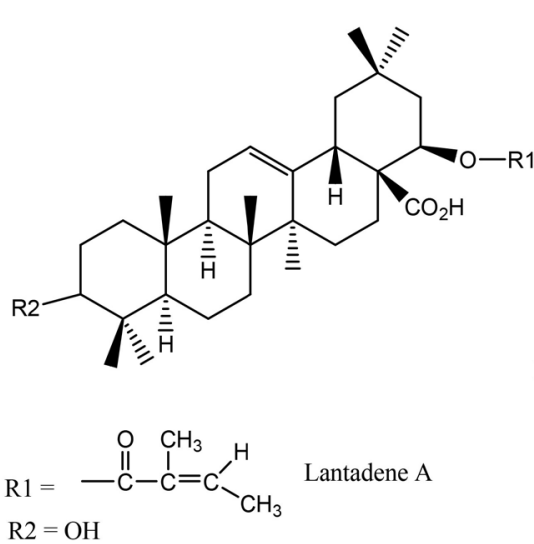

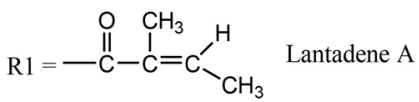

$\mathrm{R} 2=\mathrm{O}$

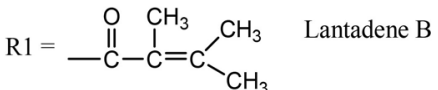

$\mathrm{R} 2=\mathrm{O}$

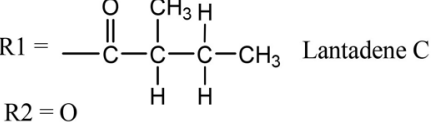

$\mathrm{R} 1=-\stackrel{\mathrm{C}}{\mathrm{C} 2=\mathrm{O}}-\underset{\mathrm{CH}_{3}}{\mathrm{C}}-\mathrm{H} \quad$ Lantadene D

Figure 9. Chemical structures of Lantadene (Pentacyclic triterpenoids) (Mpumi et al., 2016; Sharma et al., 2007).

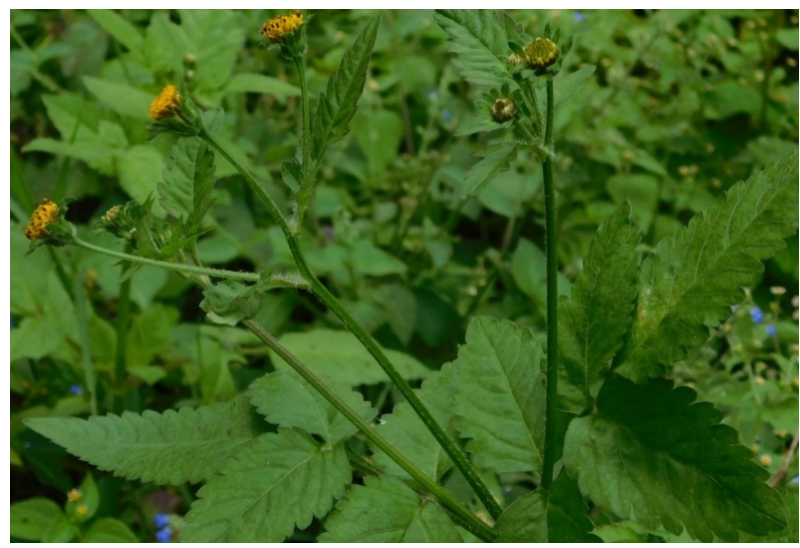

Figure 10. The picture of Bidens pilosa, a pesticidal plant (Source: Field photo).

The medicinal role offered by this plant is due to the presence of bioactive compounds. For stance, the antimicrobial and antimalarial function of B. pilosa is due to the presence of polyacetylenes in the plant [95]. Major bioactive compounds identified from leaves and flowers of the B. pilosa includes sesquiterpenes germacrene-D and $\beta$-caryophyllene and $\tau$-cadinene [90] [93] (Figure 11). Several studies have revealed the anti-insect function of the plant. A study conducted by [96] revealed the insecticidal potential of essential oils from the leaves of B. pilosa against Callosobruchus maculatus. [97] investigated the toxicity of methanol and acetone extracts of B. pilosa against stored pests of kidney beans, the Acanthoscelides obtectus (Say), and Zabrotes subfasciatus (Boheman) (Coleoptera: Chrysomelidae).

Both acetone and methanol extracts were found to cause $100 \%$ mortality of A. obtectus and Z. subfasciatus. Moreover, a study conducted by [29] [32] revealed the insecticidal potential of $B$. pilosa against insect pests of common beans such as aphids (Aphis fabae), foliage beetles (Ootheca mutabilis and O. bennigseni), pod suckers (Clavigralla spp.) and flower beetle borers (Epicauta albovittata Gestro and E. limbatipennis Pic). Although the insecticidal functions of the plant 


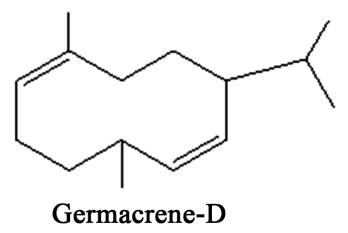

(a)

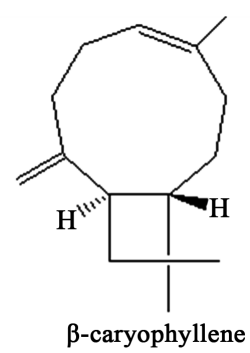

(b)

Figure 11. (a) Sesquiterpenes Germacrene-D (Yang et al., 2005) and (b) $\beta$-caryophyllene (Gertsch et al., 2008) from B. pilosa.

have been reported by many authors [29] [32] [96] however, it has not been sufficiently tested on bambara groundnut pests. Thus, future research is needed to be conducted to determine its efficacy on insect pests on bambara groundnuts.

\subsection{The Chemical and Insecticidal Potential of Tephrosia vogelii}

Tephrosia vogelii Hook. F. (Figure 12) is the herb belonging to the Family Leguminosae native to tropical Africa highly distributed in tropical America and South and Southeast Asia mainly cultivated as fish poison [98]. T. vogelii is also used as a pesticide to control pests on animals and crops on the field and storage and also enrich soil nutrients [99].

T. vogelii plant possesses diverse bioactive chemical compounds including three chemotypes (Figure 13). The chemotype 1 (C1) contains rotenoids required for pest control and chemotype 2 (C2) which do not contain rotenoids [99] [100]. However, it is reported that rotenoids (deguelin, tephrosin, $\alpha$-toxicarol, and sarcolobine) differ in their effectiveness against insect pests. Rotenone is the most active rotenoid than deguelin, tephrosin while obovatin 5 -methyl ether found in chemotype 2 is not active [100]. The Chemotype 3 (C3) is a hybrid of the chemical profiles of the Chemotype 1 and chemotype 2 [101]. Several studies have reported the insecticidal potential of the active chemical compounds of T. vogelii. For example, a study conducted by [62] revealed that T. vogelii leaf powder killed maize weevil (Sitophilus Zeamais) by causing $85.0 \%$ $-93.7 \%$ insect mortality in stored maize grain. It was found that the mortality of maize weevil was proportional to the exposure time and concentration. Closely related findings were reported by [102] when they investigated the potential of extracts from $T$. vogelii for the control of bruchids on stored legumes. Their study showed that the extracts had insecticidal potential against bruchid species (Acanthoscelides obtectus, Callosobruchus maculatus, and C. chinensis) on stored legumes. Moreover, the use of $T$. vogelii in controlling common bean pests has been reported to provide high marginal rate of return 5.62 (USD/ha) as compared with synthetic pesticide lambda-cyhalothrin pyrethroid (Karate) 4.06 USD/ha [28]. The low marginal rate of return (USD/ha) for synthetic pesticides is due to its high market price and ultimately high marginal cost than when $T$. vogelli was used. Despite the insecticidal and economic benefits offered when $T$. 


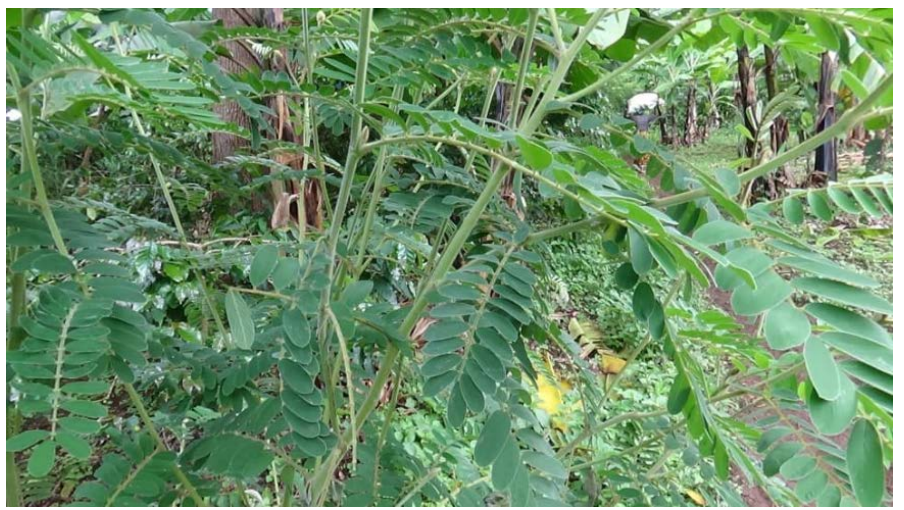

Figure 12. The picture of Tephrosia vogelii a pesticidal plant (Source: Field photo).

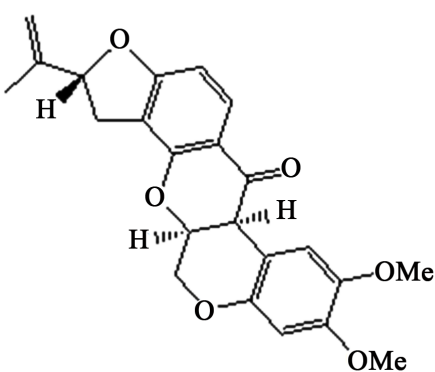

1 Rotenone<smiles>[R]c1cc2c(c3c1C(=O)[C@@]1([R])c4cc(OC)c(OC)cc4OC[C@H]1O3)C=CC(C)(C)O2</smiles>

$2 \mathrm{R} 1=\mathrm{H}, \mathrm{R} 2=\mathrm{OH} ;$ Tephrosin

$3 \mathrm{R} 1=\mathrm{R} 2=\mathrm{H}$; Deguelin

$4 \mathrm{R} 1=\mathrm{OH}, \mathrm{R} 2=\mathrm{H}$; Alpha - Toxicarol<smiles>CCCCCCCCCOc1ccccc1</smiles><smiles>COc1cc2c(c3c1C(=O)C[C@H](c1ccccc1)O3)C=CC(C)(C)O2</smiles>

6 Obovatin-5-O-methylether

Figure 13. 1 - 5; T. vogelii Chemotype compounds and 6; T. vogelii Chemotype 2 (Belmain et al., 2012; Stevenson et al., 2012).

vogelli is used to control pests on crops such as common beans, however, there is limited information on its potential in insect control on bambara groundnuts. Therefore, future research is needed to determine its potential for bambara groundnuts insect control on the field and storage.

\subsection{The Chemical and Insecticidal Potential of Vernonia amygdalina}

Vernonia amygdalina Del, is a small perennial shrub (Figure 14) belonging to the family Asteraceae that is widely distributed in tropical Africa. It is commonly referred to as bitter leaf due to its bitter taste [103]. The bitter taste is attributed to the presence of anti-nutritional factors such as alkaloids, saponins, glycosides, 


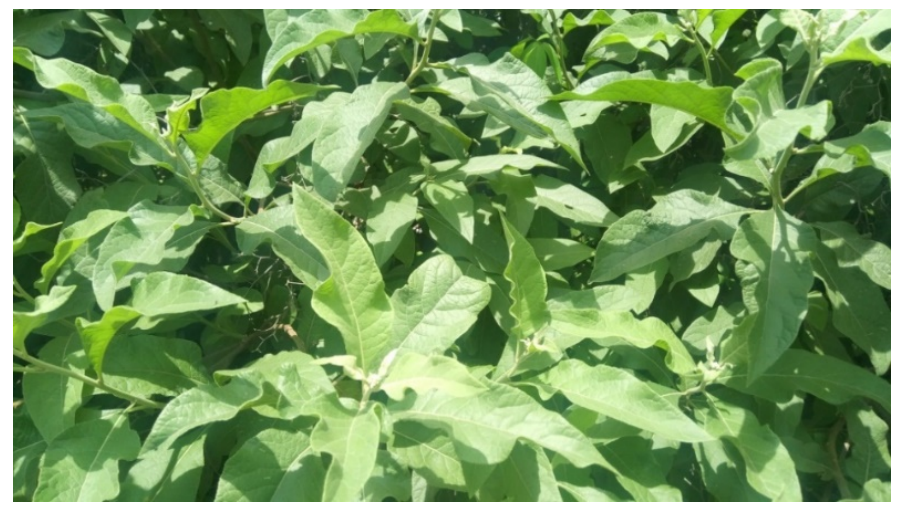

Figure 14. The picture of Vernonia amygdalina, a pesticidal plant (Source: Field photo).

and tannins [104] [105]. V. amygdalina has many traditional uses in African countries. In Nigeria, the leaves are used as a vegetable or as a spice in a soup whereby the bitterness of the leaves is reduced to the desired level by macerating in hot water [104] [106]. In Ethiopia, the leaves are used like hops in preparing tela beer [106]. The leaves are consumed mostly due to antioxidant potential [107] [108]. Moreover, in most African countries V. amygdalina is used as a folk medicine as remedies against ailments such as emesis, nausea, diabetes, loss of appetite, dysentery and other gastrointestinal tract problems, sexually transmitted diseases, diabetes mellitus [106] and antimalarial [109].

The phytochemical investigation of the leaves of $V$. amygdalina revealed presence of number of bioactive compounds such as sesquiterpene lactones including the vernolide and vernodalol (Figure 15) [108] [110], flavonoids such as luteolin, luteolin 7-O-glucosides, and luteolin 7-O-glucuronide, steroid glycosides, and vernonioside A, B, A1, A2, A3, B2, B3 and A4 [106] [108]. The sesquiterpene lactones found in $V$. amygdalina have insect antifeedant, antitumoral, antifungal, and cytotoxic properties [110]. Several studies have reported the insecticidal potential of leaf powders of $V$. amygdalina against Callosobruchus maculatus (F.) [111], beans weevil (Acanthoscelides obtectus) [112] and maize weevil (Sitophilus zeamais) [113] and field insects of common beans (Aphis fabae), bean foliage beetle (Ootheca mutabilis) and $O$. bennigseni), flower beetle (Epicauta albovittata and E. limbatipennis) and pod suckers (Clavigralla tomentosicollis, C. schadabi and C. hystricodes) in a study conducted in Tanzania and Malawi [29]. However, despite its potential in controlling insects in other crops such as common beans, future research is needed to test the efficacy of $V$. amygdalina extracts in controlling field and storage insect pests of bambara groundnuts.

\subsection{The Chemical and Insecticidal Potential of Lippia javanica}

Lippia javanica (Burm F.) Spreng (Figure 16) is an erect woody perennial herb belonging to the family Verbenaceae naturally growing in the bushes, along the roadsides, hillsides, and farms [114] in central, eastern, and southern Africa and the Indian subcontinent [115] [116]. In many African countries and Indian 
<smiles>C=CC12CCC(=O)C(=C)C1C1OC(=O)C(=C)C1C(OC(=C)C(=C)CO)C2</smiles>

Vernodalin<smiles>C=CC12CCC(=O)C(=C)C1C(O)C(C(=C)OC(=C)C(=C)CO)CC2C(=C)CO</smiles>

Vernodalol<smiles>C=C[C@]12COC(=O)C(=C)[C@@]1(C)[C@H](C)[C@@H](C(=C)C(=O)OC)[C@@H](OC(=O)C(=C)CO)C2</smiles>

Epivernodalol

Figure 15. Structure of compounds isolated from $V$. amygdalina (Farombi \& Owoeye, 2011; Green et al., 2017).

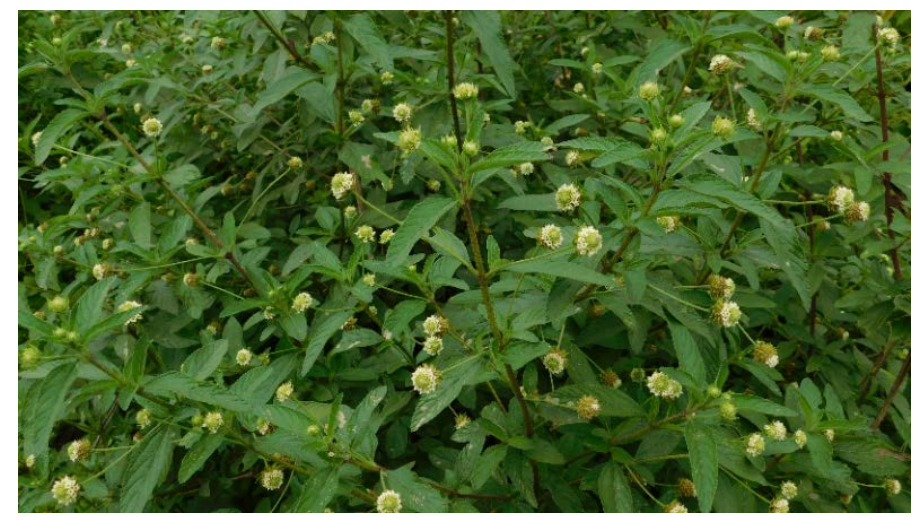

Figure 16. The picture of Lippia javanica, a pesticidal plant (Source: Field photo).

subcontinent, $L$. javanica are traditionally used as herbal tea due to its ethno-medicinal properties for the cure of ailments like colds, cough, fever, malaria, repelling mosquitos, healing wounds, diarrhea, chest pains, bronchitis, and asthma and skin diseases [117]. In Kenya, the leaves and twigs are used as food additives whereas in India, leaves are used as a leafy vegetable. In Botswana, South Africa, and Zimbabwe, the leaves, stems, and twigs are used in preparations of the herbal tea [115].

The phytochemical analysis of $L$. javanica revealed the presence of camphor as the major component with minor components such as camphene, $\alpha$-pinene, eucalyptol, Z, and E $\alpha$-terpineol, linalool, cymene, thymol, 2-carene, caryophyllene and $\alpha$-cubebene [28]. The camphor (Figure 17) a monoterpenoid commonly found in Cinnamonum camphora is reported to have the insecticidal potential [28] [32] [118] [119] [120]. Several authors including [28] [29] [32] reported the insecticidal property of $L$. javanica against field insects of common beans such as aphids (Aphis fabae), bean foliage beetle (Ootheca mutabilis and O. bennigseni) and flower beetle (Epicauta albovittata and E. limbatipennis). Another study conducted in Zimbabwe revealed that the aqueous leaf extracts of $L$. javanica 


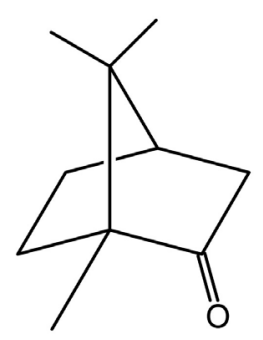

Figure 17. Chemical structure of camphor (Yim et al., 2014).

have acaricidal activity against cattle ticks and acute oral toxicity in mice [121]. Their study found that the acaricidal effect was dependent on the dose of the extract and exposure time. A study by [122] as well revealed the effectiveness of aqueous extracts of $L$. javanica leaves against the cowpea aphids. Their study demonstrated that $10 \% \mathrm{w} / \mathrm{v}$ extracts from the dried leaves powder significantly reduced the aphids infestation on cowpeas. Furthermore, the leaf powders demonstrated insecticidal potential against storage insect pests of maize and cowpeas including Sitophilus zeamais, Callosobruchus maculatus, Prostephanus truncates, Tribolium spp., and Sitotroga cerealella [33]. Although L. javanica contains bioactive compounds proved with insecticidal potential, however, it has not been evaluated against insect pests of bambara groundnuts. Therefore, future research is needed to investigate its potential against the pre-harvest and post-harvest insect pests of bambara groundnuts.

\section{Conclusion}

The production of bambara groundnut is constrained by arthropod pests such as aphids, leafhoppers, leaf beetle's groundnut jassids, pod sucking bugs, and red spider mites on the field and bruchids on the storage. The use of synthetic pesticides for pests control is common in agriculture but it is associated with undesirable effects on the environment, human health, and non-target organisms. This review has established the potential for the use of pesticidal plants as an alternative to the use of harmful synthetic pesticides. Given the diverse bioactive compounds possessed by pesticidal plants such as Croton dichogamus, Bidens pilosa, Lantana camara, Tephrosia vogelii, Vernonia amygdalina, Lippia javanica, and Tithonia diversifolia and the promising results shown by these plants against the field and storage insects of legumes (e.g. Common beans), it is, therefore, suggested that the efficacy of these plants to be tested against bambara groundnut field and storage pests to establish proper usage by smallholder farmers.

\section{Acknowledgements}

The authors acknowledge the financial support received from the Centre for Research, Agricultural Advancement, Teaching Excellence and Sustainability in Food and Nutrition Security (CREATES-FNS) through the Nelson Mandela African Institution of Science and Technology (NM-AIST). We also acknowl- 
edge the McKnight Foundation's Collaborative Research Program (CCRP) through the University of Greenwich for additional financial support in our study.

\section{Conflicts of Interest}

The authors declare no conflicts of interest regarding the publication of this paper.

\section{References}

[1] Atiku, A., Aviara, N. and Haque, M. (2004) Performance Evaluation of a Bambara Ground Nut Sheller. Agricultural Engineering International: CIGR Journal, 6, 1-18.

[2] Mpotokwane, S., Gaditlhatlhelwe, E., Sebaka, A. and Jideani, V. (2008) Physical Properties of Bambara Groundnuts from Botswana. Journal of Food Engineering, 89, 93-98. https://doi.org/10.1016/j.jfoodeng.2008.04.006

[3] Azam-Ali, S., Sesay, A., Karikari, S., Massawe, F., Aguilar-Manjarrez, J., Bannayan, M. and Hampson, K. (2001) Assessing the Potential of an Underutilized Crop: A Case Study Using Bambara Groundnut. Experimental Agriculture, 37, 433-472. https://doi.org/10.1017/S0014479701000412

[4] Massawe, F., Mwale, S., Azam-Ali, S. and Roberts, J. (2005) Breeding in Bambara Groundnut (Vigna subterranea (L.) Verdc.): Strategic Considerations. African Journal of Biotechnology, 4, 463-471.

[5] Temegne, N.C., Gouertoumbo, W.F., Wakem, G.A., Nkou, F.T.D., Youmbi, E. and Ntsomboh-Ntsefong, G. (2018) Origin and Ecology of Bambara Groundnut (Vigna subterranea (L.) Verdc.): A Review. Journal of Ecology \& Natural Resources, 2, 1-10. https://doi.org/10.23880/JENR-16000140

[6] Murevanhema, Y.Y. and Jideani, V.A. (2013) Potential of Bambara Groundnut (Vigna subterranea (L.) Verdc.) Milk as a Probiotic Beverage-A Review. Critical Reviews in Food Science and Nutrition, 53, 954-967. https://doi.org/10.1080/10408398.2011.574803

[7] Halimi, R.A., Barkla, B., Mayes, S. and King, G.J. (2018) The Potential of the Underutilized Pulse Bambara Groundnut (Vigna subterranea (L.) Verdc.) for Nutritional Food Security. Journal of Food Composition and Analysis, 77, 47. https://doi.org/10.1016/j.jfca.2018.12.008

[8] Adeleke, O.R., Adiamo, O.Q. and Fawale, O.S. (2018) Nutritional, Physicochemical, and Functional Properties of Protein Concentrate and Isolate of Newly-Developed Bambara Groundnut (Vigna subterrenea L.) Cultivars. Food Science \& Nutrition, 6, 229-242. https://doi.org/10.1002/fsn3.552

[9] Baryeh, E.A. (2001) Physical Properties of Bambara Groundnuts. Journal of Food Engineering, 47, 321-326. https://doi.org/10.1016/S0260-8774(00)00136-9

[10] Mubaiwa, J., Fogliano, V., Chidewe, C. and Linnemann, A.R. (2018) Bambara Groundnut (Vigna subterranea (L.) Verdc.) Flour: A Functional Ingredient to Favour the Use of an Unexploited Sustainable Protein Source. PLoS ONE, 13, e0205776. https://doi.org/10.1371/journal.pone.0205776

[11] Hillocks, R., Bennett, C. and Mponda, O. (2012) Bambara Nut: A Review of Utilisation, Market Potential and Crop Improvement. African Crop Science Journal, 20, $1-16$.

[12] Heller, J., Begemann, F. and Mushonga, J.N. (1997) Bambara Groundnut (Vigna subterranea (L.) Verdc.) Promoting the Conservation and Use of Underutilized and 
Neglected Crops. The Proceedings of the Workshop on Conservation and Improvement of Bambara Groundnut (Vigna subterranea (L.) Verdc.), Harare, 14-16 November 1995.

[13] William, A., Donkoh, S.A. and George, N. (2016) Adoption of Bambara Groundnut Production and Its Effects on Farmers' Welfare in Northern Ghana. African Journal of Agricultural Research, 11, 583-594. https://doi.org/10.5897/AJAR2015.10568

[14] Mayes, S., Ho, W.K., Chai, H.H., Song, B., Chang, Y. and Massawe, F. (2019) Bambara Groundnut (Vigna subterranea (L.) Verdc.) - A Climate Smart Crop for Food and Nutrition Security. In: Genomic Designing of Climate-Smart Pulse Crops, Springer, Berlin, 397-424. https://doi.org/10.1007/978-3-319-96932-9_8

[15] Mkandawire, C.H. (2007) Review of Bambara Groundnut (Vigna subterranea (L.) Verdc.) Production in Sub-Sahara Africa. Agricultural Journal, 2, 464-470.

[16] FAO (2018) Statistic of Production (FAOSTAT). Food and Agriculture Organization of the United Nations.

[17] NARI (2015) Annual Oil Seeds and Legume Crops Research Report 2014/15. Naliendele Agricultural Research Institute Annual Reports.

[18] DAFF (2016) Bambara Groundnuts. Production Guideline. Department of Agriculture, Fisheries and Forestry: Pretoria.

[19] Collinson, S., Azam-Ali, S., Chavula, K. and Hodson, D. (1996) Growth, Development and Yield of Bambara Groundnut (Vigna subterranea) in Response to Soil Moisture. The Journal of Agricultural Science, 126, 307-318. https://doi.org/10.1017/S0021859600074864

[20] Dike, M.C. (1997) Effect of Insect Pests on Pod and Seed Yields of Bambara Groundnut, Vigna subterranea L. Verde in Nigeria. International Journal of Pest Management, 43, 191-192. https://doi.org/10.1080/096708797228663

[21] Cooper, J. and Dobson, H. (2007) The Benefits of Pesticides to Mankind and the Environment. Crop Protection, 26, 1337-1348. https://doi.org/10.1016/j.cropro.2007.03.022

[22] Weinberger, K. and Srinivasan, R. (2009) Farmers' Management of Cabbage and Cauliflower Pests in India and Their Approaches to Crop Protection. Journal of Asia-Pacific Entomology, 12, 253-259. https://doi.org/10.1016/j.aspen.2009.08.003

[23] Aktar, W., Sengupta, D. and Chowdhury, A. (2009) Impact of Pesticides Use in Agriculture: Their Benefits and Hazards. Interdisciplinary Toxicology, 2, 1-12. https://doi.org/10.2478/v10102-009-0001-7

[24] Bag, D. (2000) Pesticides and Health Risks. Economic and Political Weekly, 35, 3381-3383.

[25] Gilden, R.C., Huffling, K. and Sattler, B. (2010) Pesticides and Health Risks. Journal of Obstetric, Gynecologic \& Neonatal Nursing, 39, 103-110. https://doi.org/10.1111/j.1552-6909.2009.01092.x

[26] Lozowicka, B., Kaczynski, P., Paritova, A., Kuzembekova, G., Abzhalieva, A., Sarsembayeva, N. and Alihan, K. (2014) Pesticide Residues in Grain from Kazakhstan and Potential Health Risks Associated with Exposure to Detected Pesticides. Food and Chemical Toxicology, 64, 238-248. https://doi.org/10.1016/j.fct.2013.11.038

[27] Chougourou, D.C., Agossa, C.H., Zoclanclounon, Y.A.B., Nassara, M.G. and Agbaka, A. (2016) Efficacy of Two Plant Powders as Cowpea Grain Protectants against Callosobruchus maculatus Fabricius (Coleoptera, Chrysomelideae: Bruchinae). Journal of Applied Biosciences, 105, 10152-10156. https://doi.org/10.4314/jab.v105i1.11 
[28] Mkenda, P., Mwanauta, R., Stevenson, P.C., Ndakidemi, P., Mtei, K. and Belmain, S.R. (2015) Extracts from Field Margin Weeds Provide Economically Viable and Environmentally Benign Pest Control Compared to Synthetic Pesticides. PLoS ONE, 10, e0143530. https://doi.org/10.1371/journal.pone.0143530

[29] Mkindi, A., Mpumi, N., Tembo, Y., Stevenson, P.C., Ndakidemi, P.A., Mtei, K., Machunda, R. and Belmain, S.R. (2017) Invasive Weeds with Pesticidal Properties as Potential New Crops. Industrial Crops and Products, 110, 113-122. https://doi.org/10.1016/j.indcrop.2017.06.002

[30] Mpumi, N., Mtei, K., Machunda, R. and Ndakidemi, P.A. (2016) The Toxicity, Persistence and Mode of Actions of Selected Botanical Pesticides in Africa against Insect Pests in Common Beans, P. vulgaris: A Review. American Journal of Plant Sciences, 7, 138-151. https://doi.org/10.4236/ajps.2016.71015

[31] Stevenson, P.C., Isman, M.B. and Belmain, S.R. (2017) Pesticidal Plants in Africa: A Global Vision of New Biological Control Products from Local Uses. Industrial Crops and Products, 110, 2-9. https://doi.org/10.1016/j.indcrop.2017.08.034

[32] Tembo, Y., Mkindi, A.G., Mkenda, P.A., Mpumi, N., Mwanauta, R., Stevenson, P.C., Ndakidemi, P.A. and Belmain, S.R. (2018) Pesticidal Plant Extracts Improve Yield and Reduce Insect Pests on Legume Crops without Harming Beneficial Arthropods. Frontiers in Plant Science, 9, 1425. https://doi.org/10.3389/fpls.2018.01425

[33] Chikukura, L., Mvumi, B., Chikonzo, R. and Chenzara, C. (2011) Evaluation of Selected Indigenous Pesticidal Plant Powders against Stored Maize and Cowpeas Insect Pests. The African Crop Science Conference Proceedings.

[34] Van Emden, H.F. and Harrington, R. (2017) Aphids as Crop Pests. CABI, Wallingford. https://doi.org/10.1079/9781780647098.0000

[35] Annan, I.B., Saxena, K., Schaefers, G. and Tingey, W.M. (1994) Effects of Infestation by Cowpea Aphid (Homoptera: Aphididae) on Different Growth Stages of Resistant and Susceptible Cowpea Cultivars. International Journal of Tropical Insect Science, 15, 401-410. https://doi.org/10.1017/S1742758400015733

[36] Ofuya, T.I. (1997) Control of the Cowpea Aphid, Aphis craccivora Koch (Homoptera: Aphididae), in Cowpea, Vigna unguiculata (L.) Walp. Integrated Pest Management Reviews, 2, 199-207. https://doi.org/10.1023/A:1018461320137

[37] Minja, E., Zitsanza, E., Mviha, P. and Sohati, P. (1999) A Note on Host Plants for the Groundnut Plant Hopper, Hilda patruelis, in Southern Africa.

[38] Ranga Rao, G., Rameshwar Rao, V. and Ghaffar, M. (2013) Handbook on Groundnut Insect Pests Identification and Management. Information Bulletin.

[39] Uddin, R., Azeez, K. and Lawal, A. (2017) Potentials of Two Bio-Pesticides in the Control of Some Field Insect Pests of Bambara Groundnut in Ilorin. Ethiopian Journal of Environmental Studies and Management, 10, 443-450. https://doi.org/10.4314/ejesm.v10i4.2

[40] Hill, D.S. (2008) Pests of Crops in Warmer Climates and Their Control. Springer Science \& Business Media, Berlin. https://doi.org/10.1007/978-1-4020-6738-9

[41] Begemann, F. and Mushonga, J.N. (1997) Bambara Groundnut Vigna subterranea (L.) Verdc. Proceedings of the Workshop on Conservation and Improvement of Bambara Groundnut (Vigna subterranea (L.) Verdc.), Harare, 14-16 November 1995.

[42] Abate, T. and Ampofo, J.K.O. (1996) Insect Pests of Beans in Africa: Their Ecology and Management. Annual Review of Entomology, 41, 45-73.

https://doi.org/10.1146/annurev.en.41.010196.000401 
[43] Grobbelaar, E. (2008) On the Identity of Ootheca bennigseni Weise, O. mutabilis (Schönherr) and $O$. meridiana sp. n. (Chrysomelidae: Galerucinae), Bean and Cowpea Pests in the Afrotropical Region. African Entomology, 16, 7-23. https://doi.org/10.4001/1021-3589-16.1.7

[44] Srinivasan, R. (2014) Insect and Mite Pests on Vegetable Legumes: A Field Guide for Identification and Management. AVRDC the World Vegetable Center, Shanhua.

[45] Nasruddin, A. and Gassa, A. (2014) Field Evaluation of Several Cultivated Soybean Varieties against Empoasca terminalis (Hemiptera: Cicadellidae). Florida Entomologist, 97, 995-1002. https://doi.org/10.1653/024.097.0357

[46] Aliyu, M., Ladan, T., Ahmed, B. and Abdullahi, J. (2007) Studies on the Efficacy of Black Soap and Kerosene Mixture on the Control of Pod Sucking Bugs (Clavigralla tomentosicollis stal.) on Cowpea (Vigna unguiculata (L.) Walp). Emirates Journal of Food and Agriculture, 19, 8-14. https://doi.org/10.9755/ejfa.v12i1.5171

[47] Raworth, D., Gillespie, D., Roy, M. and Thistlewood, H. (2001) Tetranychus urticae Koch, Twospotted Spider Mite (Acari: Tetranychidae). In: Mason, P.G. and Huber, J.T., Eds., Biological Control Programmes in Canada, 1981-2000, CABI Publishing, New York, 259. https://doi.org/10.1079/9780851995274.0259

[48] Mamun, M. and Ahmed, M. (2011) Prospect of Indigenous Plant Extracts in Tea Pest Management. International Journal of Agricultural Research, Innovation and Technology, 1, 16-23. https://doi.org/10.3329/ijarit.v1i1-2.13924

[49] Bagarama, F. (2016) Why Is the Red Spider Mite (Tetranychus evansi) a Threat to Dry Season Tomato Growing in Tabora, Tanzania. Huria: Journal of the Open University of Tanzania, 22, 1-10.

[50] Ahmed, M., Mamun, M., Hoque, M. and Chowdhury, R. (2012) Influence of Weather Parameters on Red Spider Mite-A Major Pest of Tea in Bangladesh. Journal of Science and Technology, 19, 47-53.

[51] Muzemu, S., Mvumi, B., Nyirenda, S., Sileshi, G., Sola, P., Chikukura, L., Kamanula, J., Belmain, S. and Stevenson, P. (2011) Pesticidal Effects of Indigenous Plants Extracts against Rape Aphids and Tomato Red Spider Mites. The African Crop Science Conference Proceedings.

[52] Ajayi, F. and Lale, N. (2000) Susceptibility of Unprotected Seeds and Seeds of Local Bambara Groundnut Cultivars Protected with Insecticidal Essential Oils to Infestation by Callosobruchus maculatus (F.) (Coleoptera: Bruchidae). Journal of Stored Products Research, 37, 47-62. https://doi.org/10.1016/S0022-474X(00)00006-0

[53] Labeyrie, V. (2013) The Ecology of Bruchids Attacking Legumes (Pulses): Proceedings of the International Symposium Held at Tours (France), April 16-19, 1980. Vol. 19. Springer Science \& Business Media, Berlin. https://doi.org/10.1007/978-94-017-3286-4

[54] Maina, Y. and Lale, N. (2004) Effects of Initial Infestation and Interspecific Competition on the Development of Callosobruchus subinnotatus (Pic.) in Bambara Groundnut Vigna subterranea (L.) Verdcourt. International Journal of Agriculture and Biology, 6, 1059-1061.

[55] Lale, N. and Vidal, S. (2001) Intraspecific and Interspecific Competition in Callosobruchus maculatus (F.) and Callosobruchus subinnotatus (Pic) on Stored Bambara Groundnut, Vigna subterranea (L.) Verdcourt. Journal of Stored Products Research, 37, 329-338. https://doi.org/10.1016/S0022-474X(00)00032-1

[56] Umar, A. and Turaki, J.M. (2014) Comparative Studies on the Biology of Callosobruchus maculatus (F.) on Soya Beans and Bambara Groundnut. Journal of Entomology and Zoology Studies, 2, 58-61. 
[57] Belmain, S., Haggar, J., Holt, J. and Stevenson, P. (2013) Managing Legume Pests in Sub-Saharan Africa: Challenges and Prospects for Improving Food Security and Nutrition through Agro-Ecological Intensification.

[58] Anjarwalla, P., Belmain, S., Ofori, D.A., Sola, P., Jamnadass, R. and S, P.C. (2016) Handbook on Pesticidal Plants. World Agroforestry Centre (ICRAF), Nairobi.

[59] Ojiako, F.O., Dialoke, S.A., Ihejirika, G.O., Ahuchaogu, C.E. and Ohiri, C.P. (2015) Comparative Performance of Pyrethrum [Chrysanthemum cinerariifolium Treviranus (Vis.)] Extract and Cypermethrin on Some Field Insect Pests of Groundnut (Arachis hypogaea L.) in Southeastern Nigeria. American Journal of Experimental Agriculture, 7, 96. https://doi.org/10.9734/AJEA/2015/15609

[60] Rugumamu, C.P. (2014) Potency of Traditional Insecticide Materials against Stored Bean Weevil, Acanthoscelides obtectus (Coleoptera: Bruchidae) in Tanzania. Huria: Journal of the Open University of Tanzania, 16, 126-139.

[61] Phoofolo, M., Mabaleha, S. and Mekbib, S.B. (2013) Laboratory Assessment of Insecticidal Properties of Tagetes minuta Crude Extracts against Brevicoryne brassicae on Cabbage. Journal of Entomology and Nematology, 5, 70-76. https://doi.org/10.5897/JEN2013.0080

[62] Ogendo, J., Belmain, S., Deng, A. and Walker, D. (2003) Comparison of Toxic and Repellent Effects of Lantana camara L. with Tephrosia vogelii Hook and a Synthetic Pesticide against Sitophilus zeamais Motschulsky (Coleoptera: Curculionidae) in Stored Maize Grain. International Journal of Tropical Insect Science, 23, 127-135. https://doi.org/10.1017/S1742758400020348

[63] Green, P.W., Belmain, S.R., Ndakidemi, P.A., Farrell, I.W. and Stevenson, P.C. (2017) Insecticidal Activity of Tithonia diversifolia and Vernonia amygdalina. Industrial Crops and Products, 110, 15-21. https://doi.org/10.1016/j.indcrop.2017.08.021

[64] Campolo, O., Giunti, G., Russo, A., Palmeri, V. and Zappalà, L. (2018) Essential Oils in Stored Product Insect Pest Control. Journal of Food Quality, 2018, Article ID: 6906105. https://doi.org/10.1155/2018/6906105

[65] Chaubey, M.K. (2017) Study of Insecticidal Properties of Garlic, Allium sativum (Alliaceae) and Bel, Aegle marmelos (Rutaceae) Essential Oils against Sitophilus zeamais L.(Coleoptera: Curculionidae). Journal of Entomology, 14, 191-198. https://doi.org/10.3923/je.2017.191.198

[66] Moyo, M., Nyakudya, I., Katsvanga, C. and Tafirei, R. (2006) Efficacy of the Botanical Pesticides, Derris elliptica, Capsicum frutescens and Tagetes minuta for the Control of Brevicoryne brassicae in Vegetables. Journal of Sustainable Development in Africa, 8, 216-222.

[67] Baroacha, R.F., Ujjan, A.A., Khanzada, M.A., Manzur, A. and Shahzad, S. (2014) Efficacy of Carica papaya and Aloe barbadensis Leaf Extracts against Mustard Aphids (Lipaphis erysimi Kalt.). International Journal of Biology and Biotechnology, 11, 141-145.

[68] Qwarse, M., Mihale, M.J., Joseph, S., Mugoyela, V., Henry, L. and Sunghwa, F. (2018) Ethnobotanical Survey of Medicinal and Pesticidal Plants Used by Agro-Pastoral Communities in Mbulu District, Tanzania. Tanzania Journal of Science and Technology, 1, 22-35.

[69] Xu, W.-H., Liu, W.-Y. and Liang, Q. (2018) Chemical Constituents from Croton Species and Their Biological Activities. Molecules, 23, 2333. https://doi.org/10.3390/molecules23092333

[70] Aldhaher, A., Langat, M., Ndunda, B., Chirchir, D., Midiwo, J.O., Njue, A., Schwik- 
kard, S., Carew, M. and Mulholland, D. (2017) Diterpenoids from the Roots of Croton dichogamus Pax. Phytochemistry, 144, 1-8. https://doi.org/10.1016/j.phytochem.2017.08.014

[71] Salatino, A., Salatino, M.L.F. and Negri, G. (2007) Traditional Uses, Chemistry and Pharmacology of Croton Species (Euphorbiaceae). Journal of the Brazilian Chemical Society, 18, 11-33. https://doi.org/10.1590/S0103-50532007000100002

[72] Castilhos, R., Grützmacher, A. and Coats, J. (2018) Acute Toxicity and Sublethal Effects of Terpenoids and Essential Oils on the Predator Chrysoperla externa (Neuroptera: Chrysopidae). Neotropical Entomology, 47, 311-317. https://doi.org/10.1007/s13744-017-0547-6

[73] Dambolena, J.S., Zunino, M.P., Herrera, J.M., Pizzolitto, R.P., Areco, V.A. and Zygadlo, J.A. (2016) Terpenes: Natural Products for Controlling Insects of Importance to Human Health-A Structure-Activity Relationship Study. Psyche: A Journal of Entomology, 2016, Article ID: 4595823. https://doi.org/10.1155/2016/4595823

[74] Ajao, A. and Moteetee, A. (2017) Tithonia diversifolia (Hemsl) A. Gray. (Asteraceae: Heliantheae), an Invasive Plant of Significant Ethnopharmacological Importance: A Review. South African Journal of Botany, 113, 396-403.

https://doi.org/10.1016/j.sajb.2017.09.017

[75] Jama, B., Palm, C., Buresh, R., Niang, A., Gachengo, C., Nziguheba, G. and Amadalo, B. (2000) Tithonia diversifolia as a Green Manure for Soil Fertility Improvement in Western Kenya: A Review. Agroforestry Systems, 49, 201-221. https://doi.org/10.1023/A:1006339025728

[76] Tagne, A.M., Marino, F. and Cosentino, M. (2018) Tithonia diversifolia (Hemsl.) A. Gray as a Medicinal Plant: A Comprehensive Review of Its Ethnopharmacology, Phytochemistry, Pharmacotoxicology and Clinical Relevance. Journal of Ethnopharmacology, 220, 94-116. https://doi.org/10.1016/j.jep.2018.03.025

[77] Moronkola, D.O., Ogunwande, I.A., Walker, T.M., Setzer, W.N. and Oyewole, I.O. (2007) Identification of the Main Volatile Compounds in the Leaf and Flower of Tithonia diversifolia (Hemsl) Gray. Journal of Natural Medicines, 61, 63-66. https://doi.org/10.1007/s11418-006-0019-5

[78] Dela Pena, C., Bartolome, D. and Banwa, T. (2013) The Potential of Tithonia diversifolia (Wild Sunflower) as Organic Foliar Fertilizer. European Scientific Journal, 4, 465-468.

[79] Osuga, I.M., Abdulrazak, S.A., Muleke, C.I. and Fujihara, T. (2012) Potential Nutritive Value of Various Parts of Wild Sunflower (Tithonia diversifolia) as Source of Feed for Ruminants in Kenya. Journal of Food, Agriculture \& Environment, 10, 632-635.

[80] Shackleton, R.T., Witt, A.B., Aool, W. and Pratt, C.F. (2017) Distribution of the Invasive Alien Weed, Lantana camara, and Its Ecological and Livelihood Impacts in Eastern Africa. African Journal of Range \& Forage Science, 34, 1-11. https://doi.org/10.2989/10220119.2017.1301551

[81] Zoubiri, S. and Baaliouamer, A. (2012) Chemical Composition and Insecticidal Properties of Lantana camara L. Leaf Essential Oils from Algeria. Journal of Essential Oil Research, 24, 377-383. https://doi.org/10.1080/10412905.2012.692910

[82] Goncalves, E., Herrera, I., Duarte, M., Bustamante, R.O., Lampo, M., Velasquez, G., Sharma, G.P. and García-Rangel, S. (2014) Global Invasion of Lantana camara: Has the Climatic Niche Been Conserved across Continents? PLOS ONE, 9, e111468. https://doi.org/10.1371/journal.pone.0111468

[83] Kalita, S., Kumar, G., Karthik, L. and Rao, K.V.B. (2012) A Review on Medicinal 
Properties of Lantana camara Linn. Research Journal of Pharmacy and Technology, 5, 711-715.

[84] Hernández, T., Canales, M., Avila, J., Duran, A., Caballero, J., De Vivar, A.R. and Lira, R. (2003) Ethnobotany and Antibacterial Activity of Some Plants Used in Traditional Medicine of Zapotitlán de las Salinas, Puebla (México). Journal of Ethnopharmacology, 88, 181-188. https://doi.org/10.1016/S0378-8741(03)00213-7

[85] Magassouba, F., Diallo, A., Kouyaté, M., Mara, F., Mara, O., Bangoura, O., Camara, A., Traoré, S., Diallo, A. and Zaoro, M. (2007) Ethnobotanical Survey and Antibacterial Activity of Some Plants Used in Guinean Traditional Medicine. Journal of Ethnopharmacology, 114, 44-53. https://doi.org/10.1016/j.jep.2007.07.009

[86] Kurade, N.P., Jaitak, V., Kaul, V.K. and Sharma, O.P. (2010) Chemical Composition and Antibacterial Activity of Essential Oils of Lantana camara, Ageratum houstonianum and Eupatorium adenophorum. Pharmaceutical Biology, 48, 539-544. https://doi.org/10.3109/13880200903193336

[87] Burns, D. (2001) Storey's Horse-Lover's Encyclopedia. Storey Books.

[88] Durbesula, A.T., Usham, G. and Kumar, R. (2015) Methemoglobinemia: Rare Presentation of Biofungicide Poisoning. IOSR Journal of Dental and Medical Sciences, 14, 10-14.

[89] Sharma, O.P., Sharma, S., Pattabhi, V., Mahato, S.B. and Sharma, P.D. (2007) A Review of the Hepatotoxic Plant Lantana camara. Critical Reviews in Toxicology, 37, 313-352. https://doi.org/10.1080/10408440601177863

[90] Lima Silva, F., Fischer, D.C.H., Fechine Tavares, J., Sobral Silva, M., Filgueiras de Athayde-Filho, P. and Barbosa-Filho, J.M. (2011) Compilation of Secondary Metabolites from Bidens pilosa L. Molecules, 16, 1070-1102. https://doi.org/10.3390/molecules16021070

[91] Bartolome, A.P., Villaseñor, I.M. and Yang, W.-C. (2013) Bidens pilosa L. (Asteraceae): Botanical Properties, Traditional Uses, Phytochemistry, and Pharmacology. Evidence-Based Complementary and Alternative Medicine, 2013, Article ID: 340215. https://doi.org/10.1155/2013/340215

[92] Arthur, G., Naidoo, K. and Coopoosamy, R. (2012) Bidens pilosa L.: Agricultural and Pharmaceutical Importance. Journal of Medicinal Plants Research, 6, 3282-3281. https://doi.org/10.5897/JMPR12.195

[93] Deba, F., Xuan, T.D., Yasuda, M. and Tawata, S. (2008) Chemical Composition and Antioxidant, Antibacterial and Antifungal Activities of the Essential Oils from $B i$ dens pilosa Linn. var. Radiata. Food Control, 19, 346-352. https://doi.org/10.1016/j.foodcont.2007.04.011

[94] Ashafa, A. and Afolayan, A. (2009) Screening the Root Extracts from Biden pilosa L. var. radiata (Asteraceae) for Antimicrobial Potentials. Journal of Medicinal Plants Research, 3, 568-572.

[95] Geissberger, P. and Séquin, U. (1991) Constituents of Bidens pilosa L.: Do the Components Found So Far Explain the Use of This Plant in Traditional Medicine? Acta Tropica, 48, 251-261. https://doi.org/10.1016/0001-706X(91)90013-A

[96] Goudoum, A., Tinkeu, L.S.N., Mbofung, M.B.N. and Moses, C. (2016) Insecticidal and Antifungal Properties of Essential Oil of Bidens pilosa Linn. Var. Radita (Asteraceae) towards Stored Bambara Groundnut Insect and Fungi Pests. Asian Journal of Agriculture and Food Sciences, 4, 66-72.

[97] Renuka, D.T. and Sharma, R. (2014) Bioefficacy of Bidens pilosa L. against Acanthoscelides obtectus (Say) and Zabrotes subfasciatus (Boheman), Stored Pests of Kidney Beans, Worldwide. International Journal of Agriculture and Crop Sciences, 


\section{7, 1470-1477.}

[98] Orwa, C., Mutua, A., Kindt, R., Jamnadass, R. and Anthony, S. (2009) Agroforestree Database: A Tree Reference and Selection Guide, Version 4.0.

http://www.worldagroforestry.org/sites/treedbs/treedatabases.asp

[99] Stevenson, P.C., Kite, G.C., Lewis, G.P., Forest, F., Nyirenda, S.P., Belmain, S.R., Sileshi, G.W. and Veitch, N.C. (2012) Distinct Chemotypes of Tephrosia vogelii and Implications for Their Use in Pest Control and Soil Enrichment. Phytochemistry, 78, 135-146. https://doi.org/10.1016/j.phytochem.2012.02.025

[100] Belmain, S.R., Amoah, B.A., Nyirenda, S.P., Kamanula, J.F. and Stevenson, P.C. (2012) Highly Variable Insect Control Efficacy of Tephrosia vogelii Chemotypes. Journal of Agricultural and Food Chemistry, 60, 10055-10063. https://doi.org/10.1021/jf3032217

[101] Mkindi, A.G., Tembo, Y., Mbega, E.R., Medvecky, B., Kendal-Smith, A., Farrell, I.W., Ndakidemi, P.A., Belmain, S.R. and Stevenson, P.C. (2019) Phytochemical Analysis of Tephrosia vogelii across East Africa Reveals Three Chemotypes That Influence Its Use as a Pesticidal Plant. Plants, 8, 597. https://doi.org/10.3390/plants8120597

[102] Koona, P. and Dorn, S. (2005) Extracts from Tephrosia vogelii for the Protection of Stored Legume Seeds against Damage by Three Bruchid Species. Annals of Applied Biology, 147, 43-48. https://doi.org/10.1111/j.1744-7348.2005.00006.x

[103] Ijeh, I.I. and Ejike, C.E.C.C. (2011) Current Perspectives on the Medicinal Potentials of Vernonia amygdalina Del. Review. Journal of Medicinal Plants Research, 5, 1051-10161.

[104] Clement, E., Erharuyi, O., Vincent, I., Joy, A., Christopher, A., Anthony, A., Onyekaba, O.J., Iftikhar, A. and Abiodun, F. (2014) Significance of Bitter Leaf (Vernonia amagdalina) in Tropical Diseases and Beyond: A Review. Malaria Chemotherapy, Control \& Elimination, 3, 120.

[105] Bonsi, M., Osuji, P., Tuah, A. and Umunna, N. (1995) Vernonia amygdalina as a Supplement to Teff Straw (Eragrostis tef) Fed to Ethiopian Menz Sheep. Agroforestry Systems, 31, 229-241. https://doi.org/10.1007/BF00712076

[106] Farombi, E.O. and Owoeye, O. (2011) Antioxidative and Chemopreventive Properties of Vernonia amygdalina and Garcinia biflavonoid. International Journal of Environmental Research and Public Health, 8, 2533-2555.

https://doi.org/10.3390/ijerph8062533

[107] Alara, O., Abdurahman, N. and Olalere, O. (2019) Ethanolic Extraction of Flavonoids, Phenolics and Antioxidants from Vernonia amygdalina Leaf Using Two-Level Factorial Design. Journal of King Saud University—Science, 31, 495-499.

[108] Igile, G.O., Oleszek, W., Jurzysta, M., Burda, S., Fafunso, M. and Fasanmade, A.A. (1994) Flavonoids from Vernonia amygdalina and Their Antioxidant Activities. Journal of Agricultural and Food Chemistry, 42, 2445-2448. https://doi.org/10.1021/jf00047a015

[109] Masaba, S. (2000) The Antimalarial Activity of Vernonia amygdalina Del (Compositae). Transactions of the Royal Society of Tropical medicine and Hygiene, 94, 694-695. https://doi.org/10.1016/S0035-9203(00)90236-0

[110] Erasto, P., Grierson, D. and Afolayan, A. (2006) Bioactive Sesquiterpene Lactones from the Leaves of Vernonia amygdalina. Journal of Ethnopharmacology, 106, 117-120. https://doi.org/10.1016/j.jep.2005.12.016

[111] Akunne, C., Ononye, B. and Mogbo, T. (2014) Evaluation of the Efficacy of Mixed Leaf Powders of Vernonia amygdalina (L.) and Azadirachta indica (A. Juss) against 
Callosobruchus maculatus (F.)(Coleoptera: Bruchidae). Advances in Bioscience and Bioengineering, 1, 86-95.

[112] Adeniyi, S., Orjiekwe, C., Ehiagbonare, J. and Arimah, B. (2010) Preliminary Phytochemical Analysis and Insecticidal Activity of Ethanolic Extracts of Four Tropical Plants (Vernonia amygdalina, Sida acuta, Ocimum gratissimum and Telfaria occidentalis) against Beans Weevil (Acanthscelides obtectus). International Journal of Physical Sciences, 5, 753-762.

[113] Asawalam, E.F. and Hassanali, A. (2006) Constituents of the Essential Oil of Vernonia amygdalina as Maize Weevil Protectants. Tropical and Subtropical Agroecosystems, 6, 95-102.

[114] Mwanauta, R.W., Mtei, K.A. and Ndakidemi, P.A. (2014) Prospective Bioactive Compounds from Vernonia amygdalina, Lippia javanica, Dysphania ambrosioides and Tithonia diversifolia in Controlling Legume Insect Pests. Agricultural Sciences, 5, 1129. https://doi.org/10.4236/as.2014.512123

[115] Maroyi, A. (2017) Lippia javanica (Burm. f.) Spreng.: Traditional and Commercial Uses and Phytochemical and Pharmacological Significance in the African and Indian Subcontinent. Evidence-Based Complementary and Alternative Medicine, 2017, Article ID: 6746071. https://doi.org/10.1155/2017/6746071

[116] Pascual, M., Slowing, K., Carretero, E., Mata, D.S. and Villar, A. (2001) Lippia: Traditional Uses, Chemistry and Pharmacology: A Review. Journal of Ethnopharmacology, 76, 201-214. https://doi.org/10.1016/S0378-8741(01)00234-3

[117] Endris, A., Asfaw, N. and Bisrat, D. (2016) Chemical Composition, Antimicrobial and Antioxidant Activities of the Essential Oil of Lippia javanica Leaves from Ethiopia. Journal of Essential Oil Research, 28, 221-226. https://doi.org/10.1080/10412905.2015.1108880

[118] Singh, P., Jayaramaiah, R.H., Sarate, P., Thulasiram, H.V., Kulkarni, M.J. and Giri, A.P. (2014) Insecticidal Potential of Defense Metabolites from Ocimum kilimandscharicum against Helicoverpa armigera. PLoS ONE, 9, e104377. https://doi.org/10.1371/journal.pone.0104377

[119] Gillij, Y., Gleiser, R. and Zygadlo, J. (2008) Mosquito Repellent Activity of Essential Oils of Aromatic Plants Growing in Argentina. Bioresource Technology, 99, 2507-2515. https://doi.org/10.1016/j.biortech.2007.04.066

[120] Chen, Z.-Y., Guo, S.-S., Cao, J.-Q., Pang, X., Geng, Z.-F., Wang, Y., Zhang, Z. and Du, S.-S. (2018) Insecticidal and Repellent Activity of Essential Oil from Amomum villosum Lour. and Its Main Compounds against Two Stored-Product Insects. International Journal of Food Properties, 21, 2265-2275.

https://doi.org/10.1080/10942912.2018.1508158

[121] Madzimure, J., Nyahangare, E.T., Hamudikuwanda, H., Hove, T., Stevenson, P.C., Belmain, S.R. and Mvumi, B.M. (2011) Acaricidal Efficacy against Cattle Ticks and Acute Oral Toxicity of Lippia javanica (Burm F.) Spreng. Tropical Animal Health and Production, 43, 481-489. https://doi.org/10.1007/s11250-010-9720-1

[122] Wafula, M.C., Mutisya, M.D. and Malombe, I. (2019) Non-Volatile Chemical Composition and Botanical Extracts from Lippia javanica (Burm. F) Spreng. in Control of Cowpea Aphids. Journal of Applied Sciences, 19, 325-330.

https://doi.org/10.3923/jas.2019.325.330 